\title{
The groundwater balance in alluvial plain aquifer at Dehgolan, Kurdistan, Iran
}

\author{
Ata Amini ${ }^{1}$ - Vafa Homayounfar ${ }^{1}$
}

Received: 24 February 2016/ Accepted: 24 June 2016/Published online: 4 July 2016

(c) The Author(s) 2016. This article is published with open access at Springerlink.com

\begin{abstract}
In this research, groundwater balance in Dehgolan plain, Kurdistan, Iran was carried out to assess changes in the level and volume of groundwater and water resources management. For this purpose, water resources supplies and consumption data, amount of charging and discharge and water level data recorded from wells and piezometers from 2010 to 2011 water year were gathered and analyzed. Rainfall and water losses of the study area were determined and required maps, including Iso-maps of the temperature, the evaporation, the groundwater level and the aquifer conductivity, were drawn by GIS software. Using the information and drawn maps and the equality of inputs and outputs data, the aquifer water balance was calculated. The results of balance equations showed that the balance is negative indicated a notably decline of groundwater equal to 15.029 million cubic meter (MCM). Such rate of decline is due to the large number of agricultural wells in the region, without considering the hydrological potential of the aquifer.
\end{abstract}

Keywords Water balance · GIS · Groundwater - Water management

\section{Introduction}

Population growth in recent decades caused increase in water demand. From ancient time up to now, groundwater has been being utilized because of restriction in

Ata Amini

ata_amini@yahoo.com

1 Kurdistan Agricultural and Natural Resources Research and Education Center, Sanandaj, Iran availability of surface water. Disregarding to groundwater extraction scheme and water over extracting has endangered groundwater resources and caused reduction of water quality (Zandi et al. 2016). Preparing a water balance in every region is crucial for water management. The water balance helps managers and officials to codify a proper plan for water resources and consumption. Water balance codification is a part of groundwater resources management and also generally water management (Rashid et al. 2015). Water balance codification helps to find out potential conditions of water resources in an aquifer or studied field and makes progression in water resources utilization possibility. Likewise, over withdrawing monitoring methods could be investigated in the zones with negative water balances. Groundwater is the largest and most accessible water resource for drinking, industrial and agricultural sectors in the world. This issue has caused the need for proper management and, consequently, many investigations and researches (Graaf et al. 2015). To determine the amount of water stored in the Mississippi basin, a research during 10 years period was conducted using balance equation with three components as: evaporation, precipitation and outgoing runoff. Results of this research showed that most important results of surface water lost in Mississippi basin are evaporation and infiltration (Seneviratne et al. 2004). Gehrels et al. (1994) extensively assessed groundwater time series in the Netherlands. Results of their research showed that the water table depletion in an extensive studied region was happened as a result of groundwater drainage, draught and extensive groundwater withdrawal by farmers. Also, they reported that as water depletes more, longer lags occur between human activities and fluctuation of 
groundwater table. Lee et al. (2007) evaluated causes of groundwater fluctuation in Daego city of South Korea during 1999-2003. They investigated precipitation, pumping from wells and subway tunnel's effects on groundwater using Man-Kendal method. Results of the research showed that subway tunnel construction has had most important effect on the region's groundwater level. Zhang et al. (2009) recognized a spatial and temporal pattern for maximum and minimum values of groundwater level in Perl River's delta region in China by using pre-whitening and Man-Kendal methods. They reported that trend of groundwater level fluctuation in the upstream of the delta is depleting and at middle and downstream of the delta an increasing trend governs the groundwater level. Zahmatkesh et al. (2001) investigated fluctuation of groundwater level in shallow aquifers at the margin of Playa in Semnan province in Iran, using 10 wells in 1999-2000 water year. Results of this study showed that average water level depletion in these 10 wells was about $5.6 \mathrm{~cm} /$ year, which is probably a signal of drought in the region. Beyzaey (2003) investigated the effect of drought on water level of Neyshabur plain aquifer. Results of this research showed that the main reason of groundwater depletion was over water withdrawal for agricultural purposes. Furthermore, they showed that the drop in groundwater levels in the alluvial plain was lower than the central and southern areas. Nejaty-Jahromy et al. (2009) studied the effect of drought on Aghily aquifer for 15 different piezometer wells during 2002-2008 stochastic period. Results of their research showed depletion in most parts of the aquifer. In this aquifer, more critical conditions govern eastern and south-western parts.

These studies show that investigating groundwater resources has been considered by many researchers and nowadays due to intensive decrease in water resources, this issue has become a necessity in integrated water resources management. Because of its land area and agricultural development, Dehgolan plain is one of the main plains in Iran which livelihoods of the region strongly depend on it. Groundwater is being extracted excessively in this plain. Successively, if this trend continues and agricultural management system in this basin does not get developed, irreparable damages would impact the watershed. In the present research, groundwater fluctuation in wet and dry periods was investigated. In addition, by determining the charge and discharge parameters of aquifer as well as the consumption of water in the watershed, changes of groundwater in both periods were calculated. Results of this research could be used extensively by researchers and experts, by quantifying the volume variation and excessive water extraction from the aquifer, to more efficiently manage water resources of Dehgolan plain aquifer.

\section{Methodology}

\section{Study area}

The study area in this research is located at the east of Sanandaj city, Kurdistan province, Iran, between $47^{\circ} 8^{\prime}$ and $48^{\circ} 12^{\prime} \mathrm{E}$ longitudes and $35^{\circ} 15^{\prime}$ and $36^{\circ} 35^{\prime} \mathrm{N}$ latitude. The maximum elevation of the region is $2880 \mathrm{~m}$ from the sea level at south and the lowest part is with the elevation of $1670 \mathrm{~m}$ at the outlet of the basin. This area has a dry and cool climate based on De Martonne climate classification. Geologically, the study area is classified in the SanandajSirjan zone and its structure is composed of old and new parts. The old part involves the formation of metamorphic Jurassic and probably related to Triassic-Jurassic period. The Dehgolan watershed contains both mountains and plains. Based on the explorative investigations, an area of free aquifer which its water balance was calculated is about $645.5 \mathrm{~km}^{2}$. The Dehgolan watershed and the aquifer boundary are shown in Fig. 1. Dehgolan city is located in this area. Increased withdrawal of groundwater in Dehgolan plain has caused a sharp drop in the groundwater levels. Thus, Dehgolan Plain is on the list of forbidden plains in Iran and no more withdrawal is allowed for any reason.

\section{Data and material}

The water balance equation incorporates water resources and consumption, geographical, physical, soil and daily hydrometeorological data. In the present research, available long-term meteorological and hydrometrical parameters, 45 years from 1966-1967 to 2011-2012 water years, were gathered and analyzed. Available data of groundwater status from 1987-1988 to 2010-2011 and the charge and discharge data of 2010-2011 water year, as basic year, were used to carry out alluvial aquifer's balance. Characteristics, location and type of 17 synoptic, climatological and hydrometric stations which are established by Iran's National Meteorological Organization and Energy Ministry are presented in Table 1. The long-term recorded data from these stations were analyzed and used in this research.

\section{Temperature}

At the present research, temperature data were analyzed to do investigation about temporal and spatial variation, extreme values of temperature in the synoptic and climatological stations of Energy Ministry and Meteorology Organization. Isotherm curvatures were drawn using ArcGIS software, and average monthly and annual temperatures in the studied region were determined. According to the recorded data, the maximum absolute temperature in 


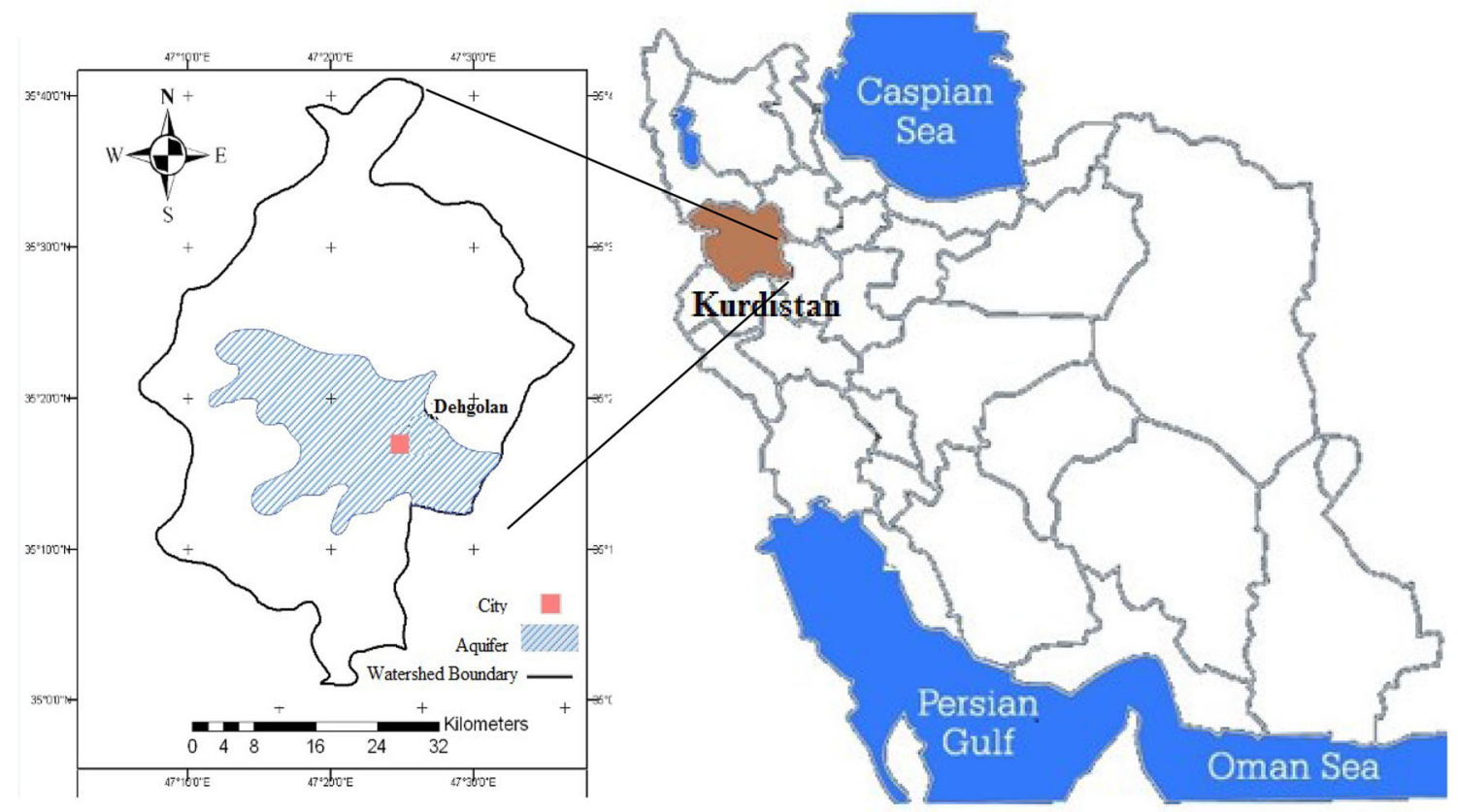

Fig. 1 Study area situation in Kurdistan, Iran

Table 1 Stations' characteristics (data from Iran's National Meteorological Organization and Energy Ministry)

\begin{tabular}{|c|c|c|c|c|c|c|}
\hline \multirow[t]{2}{*}{ Number } & \multirow[t]{2}{*}{ Name } & \multicolumn{3}{|c|}{ Coordinates (m) } & \multirow[t]{2}{*}{ Establishment date } & \multirow[t]{2}{*}{ Type of stations } \\
\hline & & $X$ & $Y$ & $Z$ & & \\
\hline 1 & Ghorveh & 782237 & 2786336 & 1906 & 1988 & Synoptic \\
\hline 2 & Ghorveh & 785044 & 2819871 & 1943 & 1998 & Climatology \\
\hline 3 & Ghamlu & 706613 & 2784975 & 1864 & 1998 & Climatology \\
\hline 4 & Dehgolan & 741556 & 2896388 & 1850 & 1976 & Climatology \\
\hline 5 & Pay Tambr & 758247 & 2809875 & 1800 & 1986 & Rain gauge \\
\hline 6 & Dehgolan & 743349 & 2798514 & 1850 & 1973 & Rain gauge \\
\hline 7 & Gorgabad & 721524 & 2798138 & 2060 & 1976 & Rain gauge \\
\hline 8 & Nadry & 737358 & 2851975 & 1910 & 1989 & Rain gauge \\
\hline 9 & Hasan Teymur & 797439 & 2858736 & 1890 & 1989 & Rain gauge \\
\hline 10 & Salamatabad & 786095 & 2841853 & 1650 & 1962 & Hydrometric \\
\hline 11 & Sangsiah & 759996 & 2806214 & 1830 & 1981 & Hydrometric \\
\hline 12 & Dehgolan & 743349 & 2798514 & 1820 & 1985 & Hydrometric \\
\hline 13 & Bolbolanabad & 733562 & 2781717 & 2025 & 1985 & Evaporation gauge \\
\hline 14 & Naserabad & 751743 & 2798668 & 1770 & 1974 & Evaporation gauge \\
\hline 15 & Kahriz & 789403 & 2843773 & 1668 & 1970 & Rain gauge \\
\hline 16 & Hasan Khan & 769879 & 2815646 & 1700 & 1991 & Rain gauge \\
\hline 17 & Tahmasb Gholy & 743382 & 2796667 & 1820 & 1963 & Storage rain gauge \\
\hline
\end{tabular}

the region was about $37^{\circ} \mathrm{C}$ and average of maximum temperature during the study period was about $32.2^{\circ} \mathrm{C}$. The coldest and warmest months of the year are February and August, respectively. The minimum absolute recorded temperature in this region was about $-13{ }^{\circ} \mathrm{C}$ and average of minimum temperature during the study period was about $-7.8^{\circ} \mathrm{C}$. The monthly temperature indices' variation is presented in Fig. 2. 
Fig. 2 Temperature monthly fluctuation

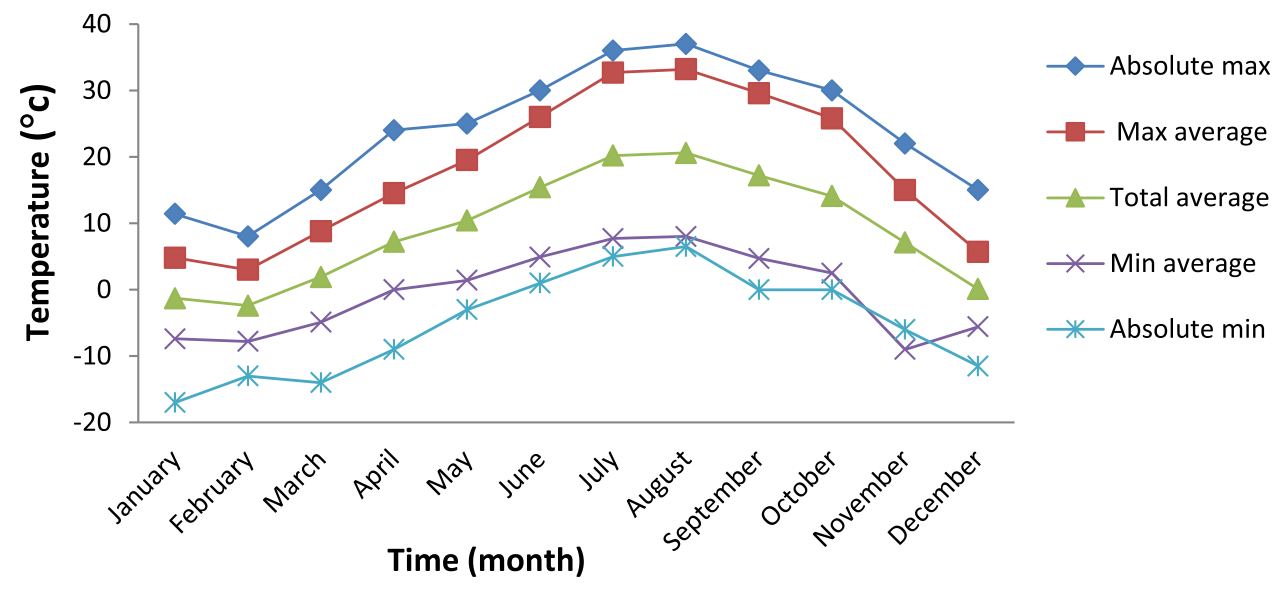

\section{Precipitation}

Recorded precipitation data of synoptic, climatology and rain gage stations were gathered to monitor precipitation trend. Trend studies were conducted for the entire stations and the regression line slope method was used for trend analysis. Then watershed was divided into homogenous regions and precipitation gradient equation for each one was developed. Rainfall was varied from 256.1 to $387.1 \mathrm{~mm}$ from the plains to the highlands. Isohyetal curvatures were derived using ArcGIS for the watershed and monthly and annual precipitation amounts were estimated individually. Isohyetal lines were drawn in these zones, then the amount of annual and monthly precipitation was estimated in the zones using these Isohyetal lines. Isohyetal lines and location of rain gage stations which are used in the present research are shown in Fig. 3.

\section{Evaporation}

In the vein of the process discussed in case of precipitation, the watershed was divided into homogeneous zones, in terms of the evaporation. To calculate mean value of evaporation, the governing equations of evaporation gradient for each of these zones were extracted. To obtain such equations at each zone, the monthly evaporations versus time were drawn and the best fit curves were extracted as third-order-polynomial curves using MS-Excel trend line tools. The zoning of the region according to evaporation rate is shown in Fig. 4. Amounts of the annual and monthly evaporation are presented in Table 2.

Mean accumulative annual evaporation in Naserabad and Bolbolanabad stations is 1686.5 and $2048.4 \mathrm{~mm} /$ year, respectively. Evaporation in Bolbolanabad station in July and evaporation in Naserabad station in August are the most. Minimum amounts of evaporation in these two stations in order occur in January and February.

\section{Aquifer groundwater balance}

There are 55 piezometer wells in the region in which the data from 34 wells were available and used in this research. The location of piezometers is shown in Fig. 5. Piezometer wells' data from 2010 to 2011 analysis show that the groundwater level fluctuates as an oscillating curvature where uprising limb continues from October up to the end of May. During this period, groundwater level rises. However, from June up to September, groundwater level has got a decreasing trend. Thus, in the present study, water year was divided into wet and dry periods. The length of the wet and dry periods is about 241 and 124 days, respectively. In the present study, water balance indices were investigated for wet and dry periods independently. Dividing water year into wet and dry periods and using composition of groundwater balance and water table fluctuations to determine water balance and specific yield are a precise and proper method (Marechal et al. 2006). Water balance of an aquifer in general could be calculated by the following equation (Mohammadi et al. 2014):

$\sum I-\sum O=\Delta V$

where $\sum I$ and $\sum O$ are summation of inflows and outflows and $\Delta V$ shows changes of water storage in the aquifer in a constant period of time. In water balances where summation of entering water and outgoing water are equal, $\Delta V=0$ and the negative value of $\Delta V$ indicates excessive water withdrawal from the constant storage of aquifer. Governing equation for the inflow and outflow components of an aquifer's water balance is as follows:

$\left(Q_{\text {is }}+Q_{\text {in }}\right)-\left(Q_{W}+Q_{\mathrm{ET}}+Q_{d}+Q_{\text {out }}\right)=\Delta V$

In Eq. (2), $Q_{\text {is }}$ is the surface recharge of the aquifer which includes percolation from recharging resources, and is calculated by the following equation: 
Fig. 3 Isohyetal lines and location of used rain gage stations

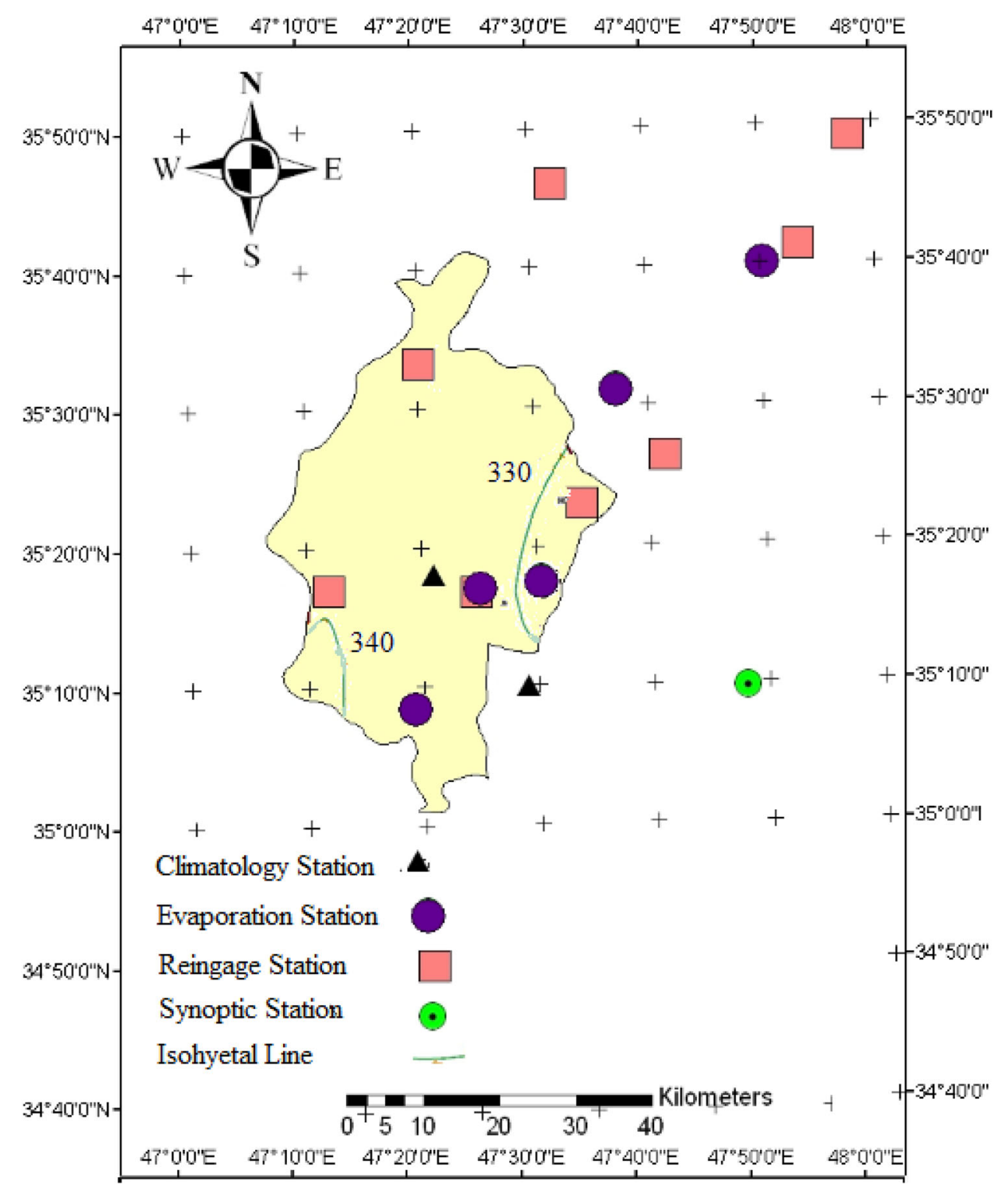

$Q_{\mathrm{is}}=Q_{P}+Q_{I}+Q_{\mathrm{SW}}+Q_{R}$

In Eq. (3), $Q_{P}$ shows percolation of rainfall from the surface of the plain to the aquifer, $Q_{I}$ shows recharging from irrigation water, $Q_{\mathrm{Sw}}$ shows recharging from urban and industrial sewage, mostly via sewage wells, and $Q_{R}$ shows recharging by surface runoff or rivers (artificial recharge is included in this term). In Eq. (2), $Q_{\text {out }}$ and $Q_{\text {in }}$ are lateral outputs and groundwater flow, respectively, which flows from hills or upstream plains. These groundwater flows were calculated by Darcy equation as follows:

$Q_{\text {in }}$ or $Q_{\text {out }}=L \times i \times T \times t$

where $L$ is the length of inlet and outlet boundaries (m), $i$ is the hydraulics gradient which is calculated by dividing mean width of the section into hightail distance between two contour lines (dimensionless), $t$ is the duration of water balance (i.e., one water year in day), and $T$ is the coefficient of transmissibility ( $\mathrm{m}^{2} /$ day). In Eq. (2), output factors, negative values, are as: $Q_{d}$ is the water draining from the aquifer system with natural or man-made drainage systems, $Q_{\mathrm{ET}}$ is the direct evaporation of groundwater in the regions where groundwater level is close to earth surface and $Q_{W}$ is the water extraction by wells, aqueduct canals and alluvial springs from the aquifer.

To define the aquifer's boundaries and bedrock, the findings of discovering investigations including digging 12 wells with accumulative depth about $1247.4 \mathrm{~m}$ and geophysical investigations using $125 \mathrm{~m}$ geo-electrical sondage conducted by Kurdistan Regional Water Authority (KRWA 2012) were used. To calculate $i$ and $T$ apart from geological 
Fig. 4 Contour lines for evaporation

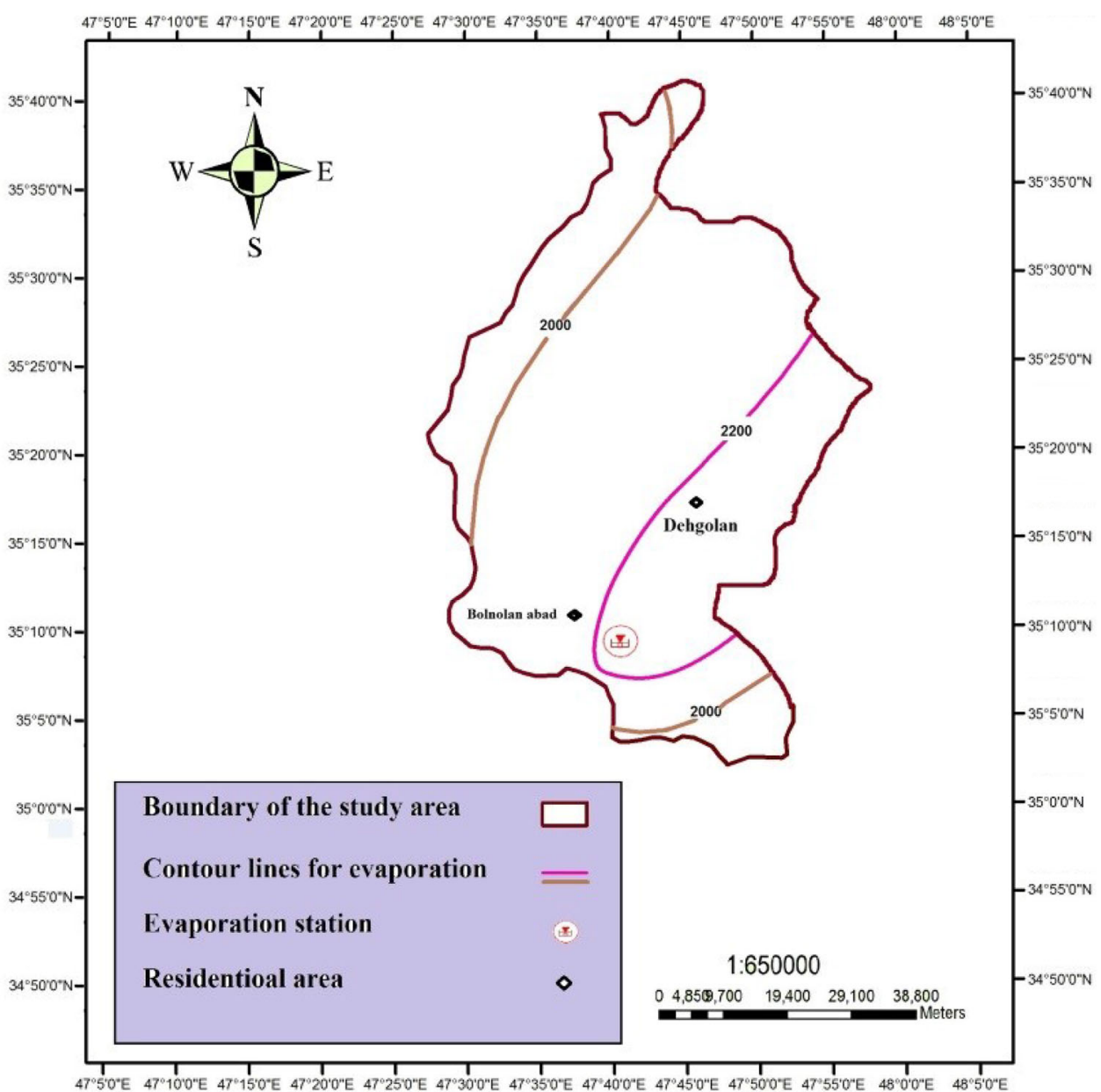

Table 2 Monthly mean evaporation (mm)

\begin{tabular}{lllllllllllllll}
\hline Station & Evaporation & October & November & December & January & February & March & April & May & Jun & July & August & September & Annual \\
\hline Naserabad & Pan evaporation & 192.7 & 101.3 & 20.6 & 0.7 & 0.7 & 8.8 & 87.3 & 164 & 257 & 294.5 & 305.6 & 253.3 & 1686.5 \\
Bolbolanabad & & 219.7 & 102.8 & 35.3 & 0.7 & 0.7 & 30 & 146.6 & 206.9 & 294.9 & 354.4 & 344.9 & 311.4 & 2048.4 \\
\hline
\end{tabular}

status of the region, finding the groundwater level and transition mechanism in the aquifer is needed. Therefore, using GIS software, groundwater level and iso-transmissibility maps were extracted and taken into use. These maps are shown in Figs. 5 and 6, respectively. The amount of percolated precipitation in the plain's surface was calculated using rainfall, potential evapotranspiration (ET0) and temperature data according to the publication No. 19 of Food and Agriculture Organization of the United Nations (FAO 1991) as:

$F=\sum_{i=1}^{12} 0.8\left(P-0.6917 T^{0.3981} \log E\right)^{0.5}$

In Eq. (5), $F$ is the annual percolation (mm), $E$ is the monthly potential evapotranspiration $(\mathrm{mm}), T$ is the annual temperature $\left({ }^{\circ} \mathrm{C}\right)$ and $P$ is the monthly precipitation $(\mathrm{mm})$.

\section{Results and discussion}

\section{Inflow components}

\section{Lateral inflow}

The components of inflow and outflow parameters of the aquifer balance were calculated separately. In addition to length of the inflow boundary and duration of water balance, to calculate the aquifer inflow, the coefficient of the aquifer transmissibility and hydraulic slope of groundwater table in inflow direction were determined. Therefore, using contour maps for aquifer transmissibility and groundwater tables, inlet and outlet sections of the aquifer were delineated in GIS based on the findings of discovering 
Fig. 5 Groundwater level and piezometric wells location

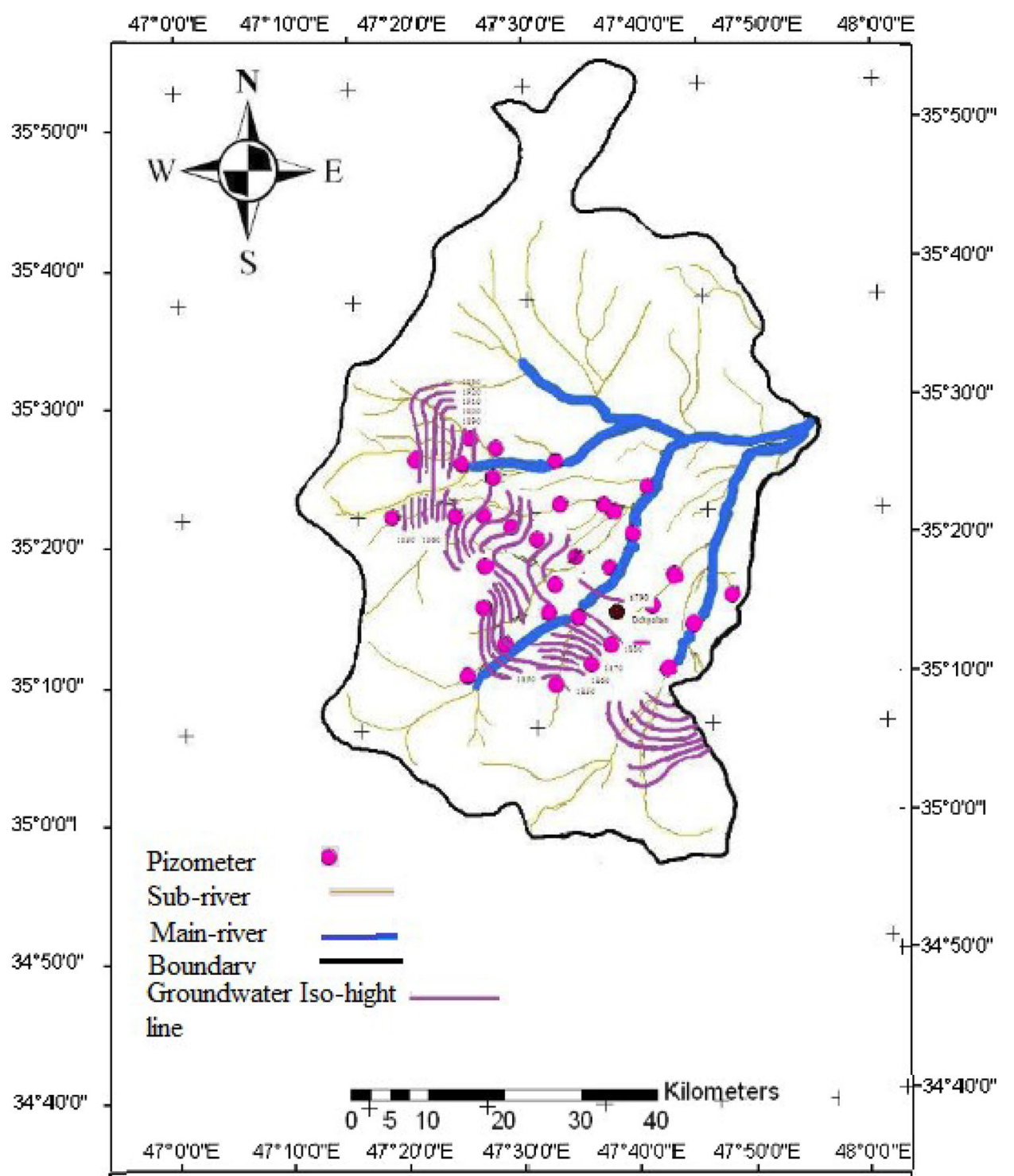

investigations (KRWA 2012). Then, using Eq. (4), the volume of lateral inflow into the Dehgolan alluvial plain aquifer in wet and dry periods was found to be 46.31 and 22.90 MCM, respectively, which represented 69.21 MCM/ year.

\section{Rainfall infiltration from aquifer surface}

After analyzing precipitation data, $348.3 \mathrm{~mm}$ was considered as annual mean precipitation. This amount of rainfall equals to $224.9 \mathrm{MCM}$ /year. In this watershed, the maximum and minimum annual precipitation were calculated as 641 and $212.7 \mathrm{~mm}$, respectively. Rainfall infiltration from surface to the plain aquifer is a part of surface recharging and was calculated using Eq. (5), extracted from publication No. 19 (FAO 1991). This amount was found as $12 \%$ of rainfall on the plain in wet period of each year, which is equal to 29.6 MCM/year. A few of consultant companies has announced this amount about $15 \%$ (KRWA 2012). In dry period of the year, there is no aquifer recharging from rainfall infiltration.

\section{Floods and inflow runoff from hills}

Seasonal and permanent rivers which heading toward the plain, charge aquifers according to groundwater table and soil texture (Amini et al. 2011). There is no permanent river in Dehgolan plain. However there are some intermittent waterways as tributaries of Talwar River which is the main river origins from highland and flowing through the plain. The inflow runoff from Talwar was calculated using the data recorded in hydrometric station. Analysis of hydrometric data showed that the total discharge of inflowing runoff from hills to Dehgolan plain is about 
Fig. 6 Iso-transmissibility map of the aquifer

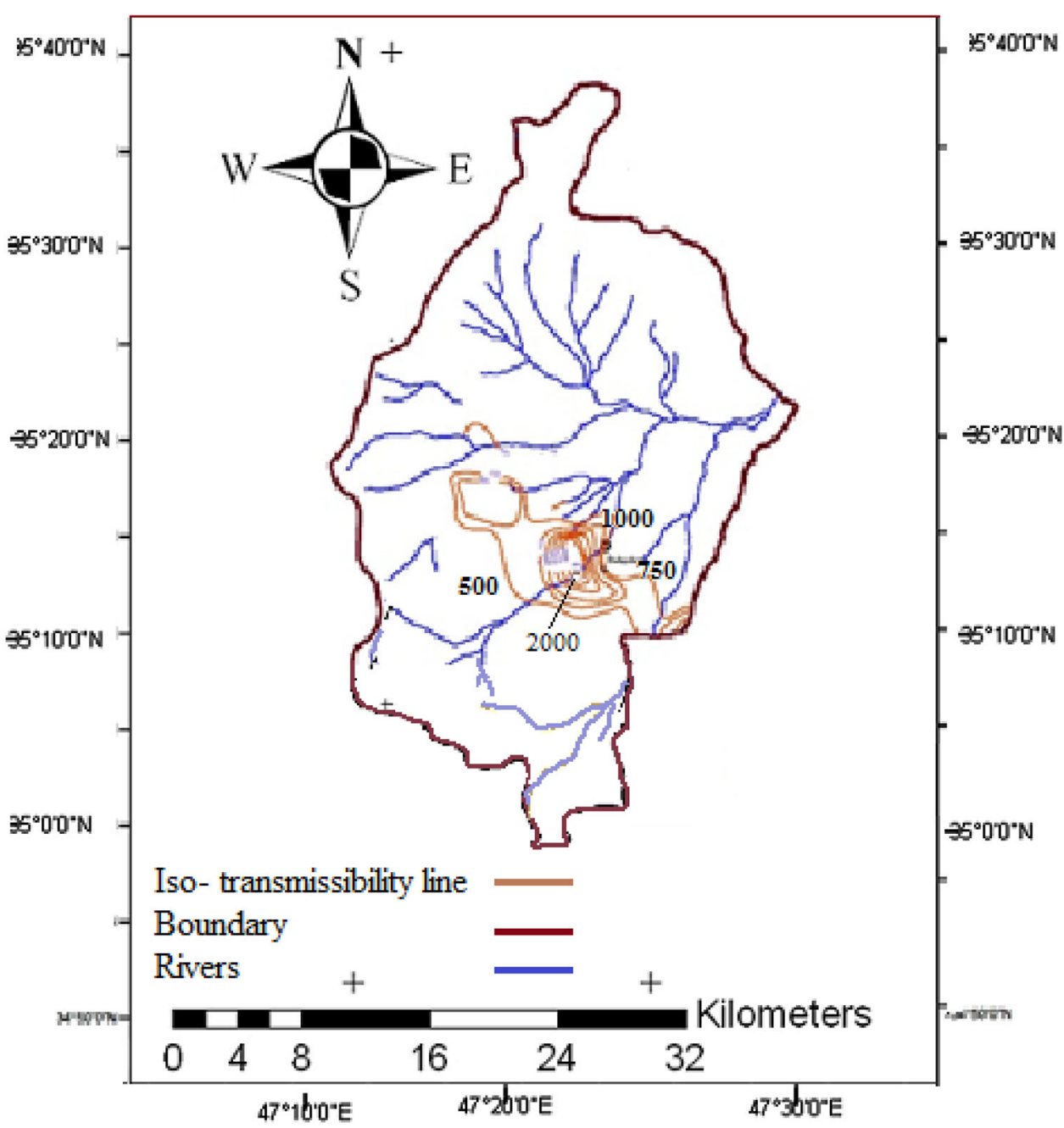

73.95 MCM/year. Considering seasonality of surface runoff in this watershed, the amount of percolation from these flows is so low and its values in wet and dry periods in order are 0.97 and 2.15 and in total are 3.11 MCM/year. Also, infiltration amount from hills in wet and dry periods was calculated as 0.93 and 4.36 MCM/year, respectively.

\section{Charging from agricultural consumed water}

In Dehgolan plain, traditional methods of irrigation are still in use, although newly pressurized irrigation systems are getting more common in this watershed. According to the recorded data, $93.7 \%$ of Dehgolan groundwater are being extracted for irrigation consumptions and also a huge discharge of surface runoff and natural springs is being used for agricultural consumptions (KRWA 2012). Considering kind and texture of soils, irrigation methods and land use condition, the amount of returning water to the aquifer was considered as $18 \%$ and $23 \%$ by KRWA (2012) and KRWA (1998), respectively. Reduction of infiltration was happened to this watershed as a result of developing irrigation system from traditional to pressurized system. In view of such reduction, this value was considered as about $15 \%$ of water consumption in the watershed. Consequently amounts of charging of aquifer from consumption water in agriculture sector during wet and dry periods of year were determined about 2.12 and 5.29 MCM/year.

\section{Industrial and drinking water infiltration}

A method of waste water ejection defines as amount of infiltration of drinking and industrial waste water. Infiltration is calculated as a percentage of water consumption for each sector. In this research, $60 \%$ of consumptions are considered as percolation of waste water of drinking and industry. This ratio is suggested by many other researchers (Jabary et al. 2009). Taking into account the volume of water consumption in these sectors, in studied alluvial aquifer, in wet and dry periods of year, returning water of 
potation in order were 1.31 and $2.26 \mathrm{MCM}$ /year. In the case of industrial sector, the volume of groundwater consumption in wet and dry periods in order is 1.51 and $0.58 \mathrm{MCM} / \mathrm{year}$ and sum of these volumes is estimated about 5.14 MCM/year.

\section{Outflow components}

\section{Groundwater withdrawal}

In Dehgolan watershed, as most of watersheds of Iran, most of water resources are used in the agricultural sector. Besides, utmost an important cause of water lost in Dehgolan watershed is agricultural consumptions. According to the recorded data by KRWA (2012) in Dehgolan plain, there are about 2528 wells, 996 springs and 60 aqueduct canals. Considering the discharges from these sources revealed that the discharge of water extraction from aquifer in wet and dry periods of year in order was calculated about 36.34 and $78.59 \mathrm{MCM} / y e a r$ and sum of the groundwater extraction in wet and dry periods was about $114.93 \mathrm{MCM} /$ year. Further analysis showed that the discharge of springs and aqueducts of Dehgolan watershed was about 78.59 and $36.34 \mathrm{MCM} / \mathrm{year}$, respectively.

\section{Aquifer evaporation}

Depletion of groundwater level because of evaporation is related to depth of water, type and texture of soil, temperature of environment, intensity of wind, relative humidity of air and concentration of TDS, while groundwater depth is the dominant factor of evaporation from aquifers. As groundwater level gets closer to the ground surface, evaporation increases. Thornthwaite method as a common method (Alesheikh et al. 2004), using groundwater depth and watershed evaporation, was used to calculate the depletion caused by evaporation. Considering evaporation contour map (Fig. 4) of groundwater depth and trivial being of evaporation in more than $3 \mathrm{~m}$ groundwater depths, in the study area, the amount of evaporation from groundwater was considered as zero.

\section{Water drainage from stream channel}

Contour lines of groundwater level define discharging or draining role of channels for aquifer. If direction of groundwater movement be from river to contour line, the river is charger and vice versa the rivers play a drainage role in the system. Contour map of groundwater (Fig. 5) shows that permanent rivers could not play a role as drainage system. So amount of drainage in the studied region was considered equal to zero.

\section{Groundwater outflow}

According to the contour groundwater map derived for Dehgolan plain (Fig. 4), there are four outlet sections in the aquifer. Considering transmission and hydraulic gradient coefficient, discharge of groundwater outflow from Dehgolan aquifer plain for wet and dry periods was determined as 13.99 and $6.99 \mathrm{MCM} / \mathrm{year}$, respectively, and summation of these values was $20.98 \mathrm{MCM} /$ year. It should be noted that the outflow from Dehgolan aquifer enters into Northern marginal alluvial zones and extracts from wells in blanks of these rivers.

\section{Groundwater balance and table}

To determine groundwater balance, inlet and outlet components were calculated in dry and wet periods in 2010-2011 water year. Results of calculation are surmised in Table 3.

Table 3 shows that in Dehgolan all the inflow components to the alluvial plain aquifer and its outflow components in 2010-2011 water year are 121.784 and 136.81 MCM, respectively. So by extracting water balance equation, Eq. (1), it was found that the water balance of Dehgolan alluvial plain aquifer was $-15.029 \mathrm{MCM} / \mathrm{year}$. This loss in groundwater volume has caused groundwater level depletion. Monthly measurements of the piezometric heads in observation wells based on a Thiessen polygon approach were used to compute annual average water table heights over the whole aquifer. The results are presented in Fig. 7.

Figure 7 shows that within 10 years intensive groundwater depletion was occurred to Dehgolan plain as $-1.2 \mathrm{~m} /$ year. This trend was intensified in recent years. In 2014-2015, groundwater depletion level reached about $-2.5 \mathrm{~m} /$ year (Amini et al. 2016).

\section{Conclusions}

In this research, long-term climatology, hydrometric, water resources and consumption data were analyzed. The results were used to drawn various GIS maps in Dehgolan alluvial plain and charging and draining values of the aquifer were taken into investigation. Water balance equation outcomes showed $-15.029 \mathrm{MCM} / \mathrm{year}$ as groundwater misplaced in Dehgolan alluvial plain aquifer which caused groundwater level depletion. According to the large subside of the plain, it appears that Dehgolan plain has achieved unreturnable situation. It must be paid attention that in this plain there are many illegal wells which extract groundwater with no restriction. It is necessary to forbid extra water extraction from agricultural wells using new consumption management methods to prevent more depletion in groundwater. Prohibiting digging new wells, obstructing illegal wells, 
Table 3 Dehgolan plain groundwater balance of 2010-2011 water year

\begin{tabular}{|c|c|c|c|c|c|c|c|}
\hline \multirow[t]{2}{*}{ Type } & \multirow[t]{2}{*}{ Components } & \multicolumn{2}{|c|}{ Wet period (241 days) } & \multicolumn{2}{|c|}{ Dry period (124 days) } & \multicolumn{2}{|c|}{ Water year (365 days) } \\
\hline & & Draining & Charging & Draining & Charging & Draining & Charging \\
\hline \multirow[t]{9}{*}{ Inflow Components } & Groundwater & & 47.01 & & 23.5 & & 70.51 \\
\hline & Rainfall infiltration & & 30.12 & & 0 & & 30.12 \\
\hline & Runoff from hills & & 4.36 & & 0.93 & & 5.29 \\
\hline & Agricultural returning water & & 2.12 & & 5.29 & & 7.41 \\
\hline & Drinking returning Water & & 2.26 & & 1.14 & & 3.4 \\
\hline & Industrial returning water & & 1.15 & & 0.58 & & 1.73 \\
\hline & Aqueducts & & 0.004 & & 0.004 & & 0.008 \\
\hline & Springs & & 0.07 & & 0.009 & & 0.016 \\
\hline & Rivers and runoff & & 0.97 & & 2.15 & & 3.12 \\
\hline \multirow[t]{8}{*}{ Outflow Components } & Underground outflow & 13.99 & & 6.99 & & 20.98 & \\
\hline & Agricultural wells & 30.26 & & 75.54 & & 105.8 & \\
\hline & Drinking wells & 3.77 & & 1.89 & & 5.66 & \\
\hline & Industrial wells & 2.31 & & 1.16 & & 3.47 & \\
\hline & Aqueducts & 0.039 & & 0.014 & & 0.05 & \\
\hline & Springs & 0.48 & & 0.037 & & 0.85 & \\
\hline & Rivers & 0 & & 0 & & 0 & \\
\hline & Aquifer evaporation & 0 & & 0 & & 0 & \\
\hline Balance & & 50.849 & 88.064 & 85.964 & 33.647 & 136.81 & 121.784 \\
\hline
\end{tabular}

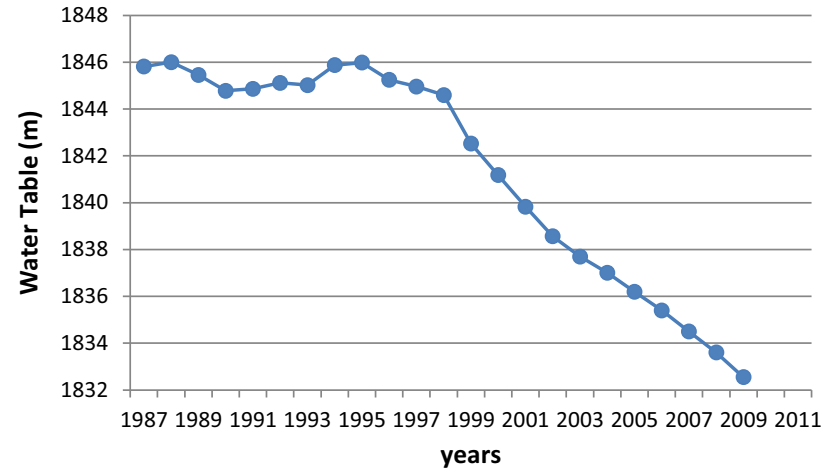

Fig. 7 Average annual water table in the Dehgolan aquifer

stopping boring bedrocks in existing wells, managing water consumption and concerning concept of virtual water are some solutions for prohibiting water resources lost in the study area. Recharging the aquifer using artificial injection of rainfall into soil layers and aquifer in wet seasons is another solution. Currently, water resources managers in Iran, to supply surface water to offset declining groundwater, are trying to use interbasin water transfer which is faced many challenges and criticizes. It is clear that if this consumption trend continues, even mentioned plans could not control this excessive depletion. Similarly, charging aquifers by rivers is not a worthy solution because it could change the quality of groundwater, which could make an intensive environmental crisis in long periods of time.
Open Access This article is distributed under the terms of the Creative Commons Attribution 4.0 International License (http://creative commons.org/licenses/by/4.0/), which permits unrestricted use, distribution, and reproduction in any medium, provided you give appropriate credit to the original author(s) and the source, provide a link to the Creative Commons license, and indicate if changes were made.

\section{References}

Alesheikh AA, Hamrah M, Halali H, Fatehi A (2004) GIS application in balance groundwater resources Talesh plain. Geogr sci Publ 3(3):99-118

Amini A, Ali TM, Ghazali H, Huat B, Aziz A, Akib S (2011) Impacts of land use change on streamflow generation in Damansara watershed, Malaysia. Arab J Sci Eng 36:713-720

Amini A, Zareie S, Taheri P, Wan KBY, Mustafa MR (2016) Drought analysis and water resources management inspection in Euphrates-Tigris Basin. In: Bucur D (ed) River basin management. InTech Publication, Romania

Beyzaey A (2003) The effects of recent drought on water resources Neyshabur plain. Master Thesis, Faculty of Geography, Tehran University, Iran, pp 122

FAO (Food and Agriculture Organization) (1991) A computer program for irrigation planning and management; FAO Irrigation and Drainage Paper No. 46: Rome, Italy

Gehrels JC, Van Geer FC, De Vries JJ (1994) Decomposition of groundwater level fluctuations using transfer modelling in an area with shallow to deep unsaturated zones. J Hydrol 157: $105-138$

Graaf IEM, Sutanudjaja EH, van Beek LPH, Bierkens MFP (2015) A high-resolution global-scale groundwater model. Hydrol Earth Syst Sci 19:823-837 
Jabary P, Ghanbarpour MR and Ashbeh A (2009) Evaluate and determine the groundwater balance in free aquifer of Sari plain. In: Fifth national conference of watershed management and science and engineering, Gorgan, Iran

Kurdistan Regional Water Authority, KRWA (1998) Groundwater study, Zharfab-Payesh Consulting Engineering Co. Final report, pp 86

Kurdistan Regional Water Authority, KRWA (2012) Extended the prohibition of Dehgolan plain aquifer, Kavosh-Abkhan Consulting Engineering Co. Final report, pp 88

Lee JY, Yi MJ, Moon SH, Cho M, Won JH, Ahn KH, Lee JM (2007) Causes of the changes ingroundwater levels at Daegu, Korea: the effect of subway excavations. Bull Eng Geol Environ 66:251-258

Marechal JC, Dewandel B, Ahmed S, Galeazzi L, Zaidi FK (2006) Combining the grounwater budget and water table fluctuation methods to estimate specific yield and natural recharge. J Hydrol 329:281-293

Mohammadi Z, Salimi M, Faghih A (2014) Assessment of groundwater recharge in a semi-arid groundwater system using water balance equation, southern Iran. J Afr Earth Sci 95:1-8

Nejaty-Jahromy Z, Chitsazan M, Mirzaei E, Abodi T (2009) The impact of drought on groundwater resources in Aghili plain. In:
Proceeding of second national conference on effects of drought and ways to its management, Esfahan, Iran, pp 102-109

Rashid H, Al-Shukri H, Mahdi H (2015) Optimal management of groundwater pumping of the cache critical groundwater area, Arkansas. Appl Water Sci 5(3):209-219

Seneviratne SI, Viterbo P, Luthi D, Har C (2004) Water balance computations of seasonal changes in terrestrial water storage: case study for the Mississippi river basin and methodology validation against observations from illinois. $\mathrm{J}$ Wetl 318:483-497

Zahmatkesh G, Alavipanah K, Zehtabaian GR (2001) Study of shallow groundwater table fluctuations in the Semnan playa margin, Case study: Semnan. Biaban J 6(2):15-30

Zandi J, Taherei P, Hashim R, Motamedi S (2016) Mapping of regional potential groundwater springs using logistic regression statistical method. Water Resour 43(1):48-57

Zhang W, Yan Y, Zheng J, Li L, Dong X, Cai H (2009) Temporal and spatial variability of annual extreme water level in the Pearl River Delta region, China. J Glob Planet Change 69:35-47 